\title{
ニつの同心円の位置ずれを考慮した円周魚眼画像 におけるタイヤ接地点からの車両位置推定法*
}

\author{
廣瀬 健一 †鳥生隆 • 濱裕光
}

\author{
A Position Estimation Based on Tire-Road Contact Points \\ Considering Displacements of Two Concentric Circles \\ on a Circular Fisheye Image*
}

Kenichi Hirose ${ }^{\dagger \ddagger}$, Takashi Toriu ${ }^{\ddagger}$ and Hiromitsu HAMA

In this paper, we propose a new method for estimating the positions on a road based on detected tire-road contact points taking the distortion on circular fisheye images into consideration. In our proposed method, we use the distortion parameters of two concentric circles composed of the inner wheel and the outer tire by considering projection system of fisheye lens, and the searching the gray scale profiles in the vertical direction are derived from each pixel that is the outline of the wheel region. The effectiveness of the proposed method is confirmed through experimental results.

\section{1.はじめに}

安全な自動車運転環境と円滑な交通状態は誰もが望 むことであり，近年 ITS (Intelligent Transportation Systems) に関する研究開発が注目されている。乥こで はドライバー支援システムや交通監視システムにおいて， ビジョンベースでの車両の検出や位置推定に関する研究 が盛んに行われている $[1-5]$. これらの研究のほとんど は，車両の前面および後面の画像か対象である．車両側 面の画像を対象とする研究は, より広範囲な視野を必要 とし, 交通監視システムに関する研究, 駐車車両の計数 や走行車両の検出を目的とする研究が一部で行われてい るだけである $[6-10]$. しかし，これらの多くは通常のカ メラを使用するものであり，車両全体を捉えるためには カメラから対象車両まである程度以上の距離が必要とな る．また，超広角なカメラであるオムニカメラを用いた 車両側方を処理対象にした研究も行われている [11-13] . これらの研究は広範囲な情報取得において有効であるが， オムニカメラは乥の性質上, カメラに間近な車両の検出

* 原稿受付 2009 年 8 月 26 日

$\dagger$ 産業技術短期大学 情報処理工学科 Department of Information Engineering, College of Industrial Technology; Nishikoya 1-27-1, Amagasaki-shi, Hyogo 661-0047, JAPAN

\# 大阪市立大学大学院 工学研究科 Graduate School of Engineering, Osaka City University; Sugimoto 3-3-138, Sumiyoshi-ku, Osaka 558-8585, JAPAN

Key Words: position estimation, two concentric circles, gray scale profile, circular fisheye.
には向いていない .

本研究では, 広視野である魚眼カメラを使用して車両 側面の画像を対象に比較的近距離にある車両の検出と位 置推定を目的とする . 車両側面に固有の特徵は, 車体下 部には車輪が必ず存在することである .ここでは, 魚眼 カメラから取得される画像からホイール領域の抽出を行 い, 乥こからタイヤの接地点をサブピクセル精度で検出 し, 道路上の車両の位置推定を行う方法を提案する. 通 常カメラにおいて車輪部分を撮影した場合は, 車輪の形 状は円あるいは楕円であり，Fig.1(a)の左図のように， タイヤの接地点は車輪の中心から真下にある (図中の

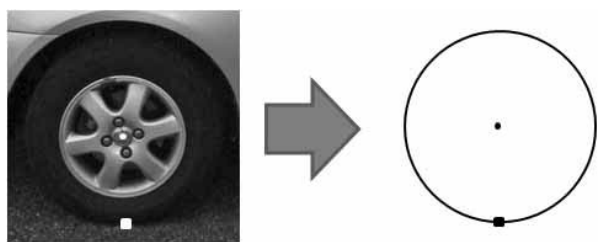

(a) By normal camera

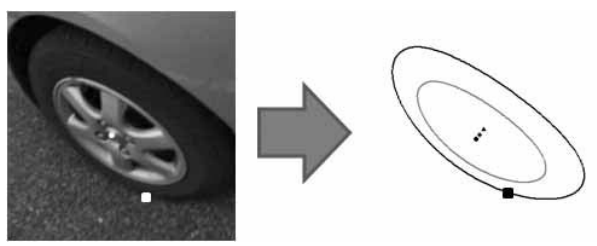

(b) By fisheye camera

Fig. 1 Comparison of normal and fisheye camera images 
丸い点が中心点，四角の点が接地点を示す）.この場合 は，画像上のホイールとタイヤの中心点および重心点の 位置はすべて一致するので，右図のように車輪を一つの 円と考え，画像から円領域を抽出して，兴の重心位置か ら比較的容易に接地点が検出できる. しかし, 魚眼カメ ラで撮影した場合は, カメラ正面で円周画像の中央部に 射影されるときは, Fig. 1(a) と同樣であるが, 周辺部に 射影されるときは，魚眼レンズ特有の射影歪みのため， Fig. 1(b) の左図のように接地点位置は中心点の射影位 置の真下にはならない . またこのとき , 右図のように円 の中心の射影点，ホイールの重心点およびタイヤの重心 点は, 光れ光れ位置が異なる (図の中央の 3 点で左下か ら順に中心射影点, ホイール重心点, タイヤ重心点を示 す）.したがって，魚眼カメラを用いたタイヤ接地点の 検出では，この二つの同心円形状の歪みによる位置ずれ を考慮する必要がある．一般に魚眼カメラを用いる場合 は，射影歪みを初めに補正した正像画像に変換した後に， 通常カメラと同樣の処理で接地点の検出が行われる.し かし，本論文では，正像画像に変換することなく，この 位置ずれを考慮した中心射影点の推定と濃淡値プロファ イルの探索を用いて，魚眼画像から直接タイヤ接地点を 検出する方法を提案する．ここでは，検出精度をあげる ために, 濃淡値プロファイルからのタイヤ接地点の検出 をサブピクセル精度で行う方法も併せて提案する．

C. Lai ら [7] は, 通常カメラから取得される画像から ホイールを棈円近似して抽出した後にタイヤ接地点の検 出と位置推定を行っているが，この処理方法は正像画像 が対象であり，われわれのアプローチには光のままでは 適用できない．またほかにも，ホイール抽出を対象とし た，O. Achler ら [8]やY. Iwasaki ら [9] の研究がある. いずれも固定された通常カメラを用いた背景差分を基に ホイール抽出を行っている. 通常カメラでは, 前後輪二 つのホイールを同時に撮影するためには, カメラから数 $\mathrm{m}$ 以上の距離が必要であり, 本研究で対象とする比較的 近距離での車両位置推定には向かない．K. Kato ら [10] は，魚眼カメラを用いて動画像の軌跡に基づく車両の 3 次元形状の再構成を提案している.この研究もまた，背 景差分を用いるためにカメラを固定する必要があり，力 メラに対する車両の進行方向などにも制約があり，汎用 性に欠ける .

既存研究のほとんどが車輪を一つの円あるいは楕円で あると仮定し，通常カメラからの正像画像を対象に処理 を行っているが, 本研究では, 車輪がホイール部分とタ イヤ部分の二つの同心円から成り，地面に垂直であると 仮定して，二つの同心円における魚眼カメラの射影歪み による特徵点の位置ずれを考慮する点でほかと異なる． また，本方法は，背景差分などの環境のグローバルな特 徵は用いずに，円周魚眼画像から得られる対象車両が持 つローカルな特徵を用いるので, 固定カメラ, 車載カメ ラいずれにおいても適用できる．さらに，車両検出や位
置推定だけでなく，車両方向の推定やホイールベース長 の計測などさまざまな応用展開も可能となる .

本論文の構成は次の通りである . まず 2.では, 車両位 置推定法の概要について述べる .つぎに 3 . では, 円周魚 眼画像における二つの同心円形状の特徵点の位置ずれに ついて述べ，4.では，弚のずれを考慮したタイヤ接地点 のサブピクセル精度の検出方法を提案する . 5. では, 実 験結果を通して提案方法の有効性について考察する . 最 後に 6.で, 研究成果と今後の課題についてまとめる.

\section{2. 車両位置推定法}

筆者らが提案する車両位置推定法の処理手順を Fig. 2 に示す．本方法では，魚眼カメラの使用環境が決まると 魚眼カメラの射影歪みを考慮するため, あらかじめ車輪 位置に対する形状歪みを計算して, パラメータテーブル を作成する.乥して，このパラメータに基づいて，キャ プチャされる円周魚眼画像からタイヤ接地点を検出し， 兴の道路上の位置を推定する.ここでは，この推定され た車輪位置を車両位置とする。

提案方法における対象車両と魚眼カメラの関係を Fig. 3 に示す. カメラ光軸は地面に平行とする . カメラ位置を 原点とする魚眼カメラの 3 次元空間座標系を図のように

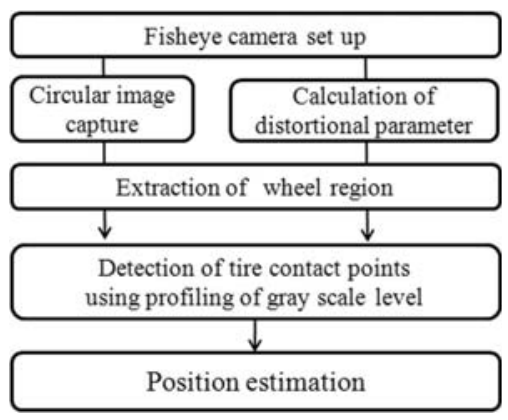

Fig. 2 Overview of our algorithm

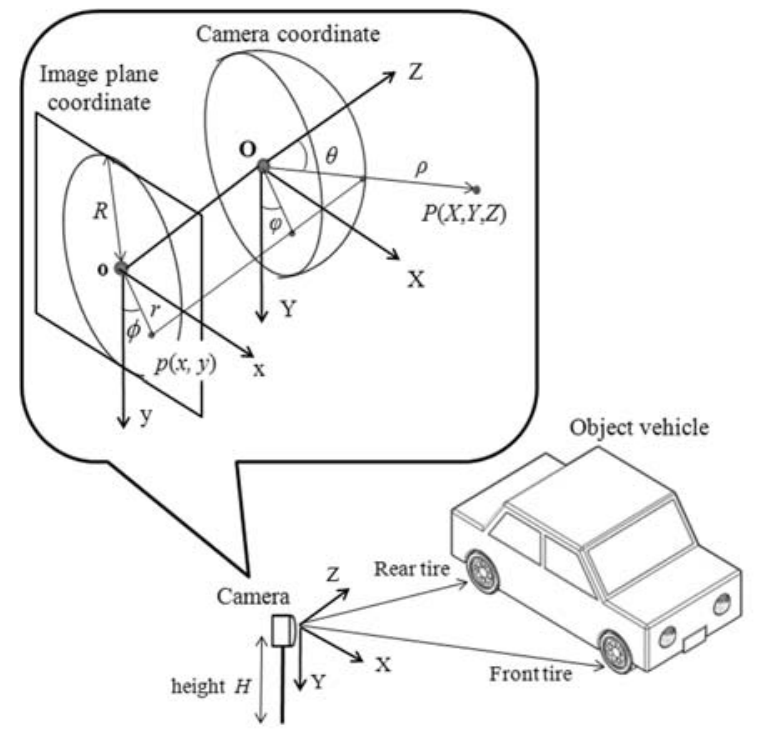

Fig. 3 The relation between the camera and a vehicle 
設定する．また，魚眼カメラの 3 次元座標系と撮像面で ある 2 次元の画像平面座標系の関係を図の上部に示す． 魚眼カメラの座標系を O-XYZ とし，画像平面の座標系 を $\mathrm{o}-\mathrm{xy}$ とする．魚眼レンズの光軸方向を $\mathrm{Z}$ 軸とし, $\mathrm{x}$ 軸，y軸は光れ光れ X 軸，Y軸と平行に設定する。この ときカメラ座標系における 3 次元空間上の点 $P(X, Y, Z)$ は, 極座標 $(\rho, \theta, \varphi)$ で表され，図のように画像平面上の 点 $p(r, \phi)$ に射影されるとする . また,$O P$ と $o p$ は同一 平面上にあり， $\varphi=\phi$ となる .ここでは，円周魚眼画像 上で検出されるタイヤ接地点の 2 次元座標值を基に , 力 メラ座標系における道路平面上の位置 $X$ と $Z$ の值が推定 される.ここで，使用する魚眼レンズの射影方式か既知 であれば， 3 次元平面上の点 $P$ と画像平面上の射影点 $p$ の関係式が求まる.本研究では, 画角 180 度の等立体角 射影方式の魚眼レンズを使用するので, 点 $P$ のカメラ光 軸からの角度を $\theta$ とすると，画像平面上の射影中心 $\mathbf{o}$ らの点 $p$ の像高 $r$ は (1) 式で表される .

$$
r=\sqrt{2} R \sin \left(\frac{\theta}{2}\right)
$$

ここで, 定数 $R$ は,$\theta$ が 90 度のときの像高であり，円 周画像の画像半径である . また , カメラの高さを固定し て撮影したとき，対象点をタイヤ接地点に限定すると接 地点の位置 $Y$ はカメラの高さと等しくなり，検出される タイヤ接地点の画像上の座標値 $(x, y)$, カメラの高さ $H$ および画像半径 $R$ を用いて，タイヤ接地点の道路上の位 置 $(X, Z)$ は, $(2)$ 式で計算される .

$$
=\left(H \times \frac{x}{y}, H \times \frac{\sqrt{\frac{x^{2}}{y^{2}}+1}}{\tan \left(2 \sin ^{-1} \frac{\sqrt{x^{2}+y^{2}}}{\sqrt{2} R}\right)}\right)(2
$$

したがって，本提案方法では，魚眼画像におけるタイヤ 接地点の高精度な検出が必要となる．

\section{3. 二つの同心円の位置ずれ}

一般に, 車輪はト一角，キャンバー角などいろいろな 方向で角度を付けて設置されているが, 兴れらの角度は 1 度程度で非常にわずかであるため，ここでは車輪形状 を次のように仮定する。

・車輪の表面はホイール輪郭部とタイヤ輪郭部による 二つの同心円形状である

・車輪は接地点で地面に垂直に立っている.

- 車輪の表面は平面で近似される.

提案方法では車輪表面の二つの同心円形状が魚眼カメ ラで撮影されると仮定して , 魚眼カメラの使用環境 (カ メラの高さ，画像サイズ，射影方式，タイヤおよびホ イールの半径) が決まると，初期処理でこの円形状が射

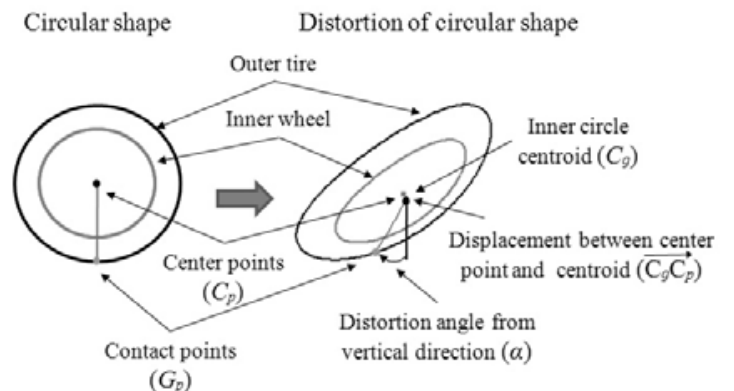

(a) Distortion parameters of concentric circles

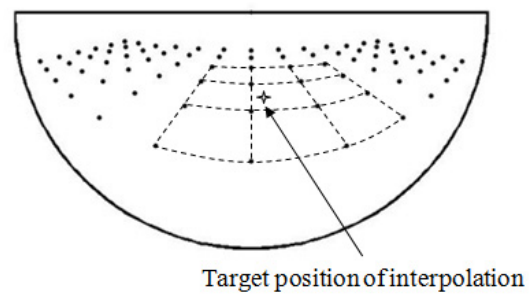

(b) Parameter position on the image

Fig. 4 Distortion parameters in circular fisheye image

影されて生じる歪み形状のパラメータをあらかじめ計算 し，画像位置に応じたパラメータテーブルを作成してお く.タイヤ接地点は, この形状パラメータの中でもとく に, 特徵点の位置ずれを考慮した中心射影点の推定と濃 淡値プロファイルの探索を用いて検出される .

円の歪み形状パラメータを Fig. 4(a) に示す .このと き, 同図の左に示す円の中心から接地点を結う鉛直線分 は，魚眼射影により歪んだ曲線となり，魚眼画像上での 接地点の位置は , 右図のように円の中心射影点の真下か らずれる．この位置ずれを考慮するために, 曲線を直線 近似して，弚の傾き角度を定義する (以下，二の角度を 歪み角と称す） . また, 左図では同心円の中心点と内側 の円の重心位置は一致するが , 右図では射影歪みにより 円の中心射影点と内側の円の歪み形状の重心位置はずれ る.したがって，この位置ずれによる中心射影点の重心 からの平行移動量を, 後述のホイール領域の重心に基づ く中心射影点の位置推定に用いる. 歪み形状パラメータ テーブルとして, 内側の円 (仮想ホイールの輪郭) の重 心位置 $\left(C_{g}\right)$ とバウンディングボックスの大きさ (高さ , 幅）, 円の中心の射影点 $\left(C_{p}\right)$ の重心からの平行移動量 (ベクトル $\left.\overrightarrow{C_{g} C_{p}}\right)$ および歪み角 $(\alpha)$ を, 地面上の格子位 置に応じてあらかじめ計算しておく .

本研究では, タイヤの半径を普通乗用車の平均的な大 きさである $30 \mathrm{~cm}$ と仮定する. また, 車載カメラでの適 用を想定してカメラの高さは $100 \mathrm{~cm}$ に固定する .この とき使用するカメラによる円周魚眼画像の画像半径 $R$ が 決まると, 画像計測可能なカメラからの相対位置やパラ メータテーブルの格子間隔は (2) 式を基に計算すること ができる .ここでは, 後述のカメラ仕樣に基づく画像計 
測可能な範囲を計算して , 位置 $X$ が $-300 \mathrm{~cm}$ 300 cm , $Z$ が $30 \mathrm{~cm}$ 300 cm の地面上 $50 \mathrm{~cm}$ 間隔の格子位置に 置かれた半径 $30 \mathrm{~cm}$ と $20 \mathrm{~cm}$ のつの同心円が , 円周魚 眼画像上に射影されて生じる歪み形状のパラメータを計 算して , パラメータテーブルを作成する．このとき，各 格子位置でのパラメータである重心位置 $C_{g}$ は魚眼画像 上で , Fig. 4(b)のように放射状に分布する.実測におけ る格子の中間位置 (たとえば, 図の十字の星印) でのパ ラメータ值は, 周囲 16 点の $C_{g}$ の位置 (図の点線で結ば れた点) を魚眼画像の中心からの極座標値で表して，光 の值を基に周囲点のパラメータ值からキュービックスプ ライン補間 [14] で算出する . なお , 格子位置の間隔を前 述のように設定しても，理論的な誤差の推定值は $0.1 \mathrm{~cm}$ 以下であり，十分な精度で補間されることは確認されて いる.

\section{4. 濃淡値プロファイルを用いたタイヤ接 地点検出}

タイヤ接地点の検出処理として, 濃淡值のプロファイ ルを利用する方法を提案する . タイヤおよび道路面は一 般的に比較的濃淡值の低い領域であるが，これらの接触 部分には必ず影が生じ，炎の影の部分は周囲よりも濃淡 值が低くなる．このことから，ホイールの輪郭部分から 路面方向に向けて濃淡値のプロファイルを調べ, 濃淡值 が最小となる点をタイヤと路面の接触点と考える．

提案方法では, まずソーベルフィルタによるエッジ抽 出を用いて円周魚眼画像からホイール領域を抽出する. エッジ抽出処理では，画素ごとに 8 方向のソーベルフィ ルタによるエッジ強度を光れ光れ計算し，弚の中で最大 の值をとる方向を各画素のエッジ方向とする．また，同 じ方向を持つ隣接画素の集合を方向エッジとする．隣接 する複数の方向エッジを一つのグループエッジ領域とし てホイール候補領域とする．候補領域内にある方向エッ ジの方向数, 方向エッジ間の接続関係を調べるととも に , 領域のバウンディングボックスの大きさと前述の歪 み形状パラメータの一つである内側の円のバウンディン グボックスの大きさを領域の画像上の位置に応じて比較 することでホイール領域を特定する．特定された領域の バウンディングボックスの縦横ともに 2 倍の大きさでタ イヤを含む矩形画像を切り出す . この矩形画像は大部分 がタイヤおよび道路面であるため，車体や背景を含む円 周画像全体に比べて, 濃淡值が低くコントラストも低い 画像である . 画像撮影時の日照条件による明るさの違い に対応するため，この矩形画像に対してガンマ変換を行 い, コントラストを調整する

つぎに, 特定されたホイール領域の画像上の重心位置 に対応する歪み形状パラメータを前述のパラメータテー ブルから求めて, ホイール領域の重心位置からホイール の中心射影点 $C_{p}$ を推定する . この $C_{p}$ の推定位置を基
にタイヤ輪郭部に向かって濃淡値のプロファイルを探索 して, タイヤの接触点を求める.このときホイール部分 の凹凸の影による誤検出を避けるために , プロファイル は, ホイール輪郭部から外側を調べる. 通常は車輪の接 地点 $G_{p}$ はホイールの重心位置の真下にあり，光の最下 部で路面に接地する.しかし, 円周魚眼画像では, 前述 の歪み角 $\alpha$ を考慮する必要がある .

一般に $\alpha$ を考慮するタイヤ接地点の検出方法として， $\alpha$ 方向に濃淡值プロファイルを探索する方法が考えられ る .この方法では, 推定された $C_{p}$ から $\alpha$ の方向に向か う直線に沿って最近傍の画素位置を順に探索して濃淡值 プロファイルを作成する . そこで濃淡值が最小となる画 素位置を接地点 $G_{p}$ とする．しかし，この方法では $G_{p}$ はピクセル精度の検出であり, 誤差を含む . 光こで, サ ブピクセル精度で $G_{p}$ を検出するため, $\alpha$ 方向の直線上 の濃淡值プロファイルを探索する方法を考える . この方 法では, $y$ 座標の画素位置に対する直線上の $x$ 座標值を 求め, 兴の $x$ 方向の両近傍の画素位置の濃淡值を基に線 形補間して直線上での濃淡值を求める．また，このプロ ファイルは $y$ 値に対してはピクセル単位であるため, 濃 淡值が最小となる位置はパラボラフィッティングによる サブピクセル推定 $[15]$ を用いて $G_{p}$ を検出する . しかし， この方法はサブピクセル推定により高精度に検出できる が , 一つの濃淡値プロファイルの探索による接地点検出 はノイズによる影響を受けやすく，安定性に欠ける．

光こで本論文では, 鉛直方向の複数の濃淡值プロファ イルを用いるタイヤ接地点のサブピクセル検出方法を 提案する . 提案方法におけるタイヤ接地点の検出手順を Fig. 5 に示す . まず, 抽出されたホイール領域の輪郭下 部の各画素から鉛直方向に濃淡值プロファイルを求める . また, 各プロファイルで濃淡值が最小となる位置をパラ ボラフィッティングを用いてサブピクセル精度で推定し， タイヤ輪郭部における路面との接触点列を求める . つぎ に, この接触点列の 2 次の近似曲線を求めて, タイヤ輪 郭線を得る.また，推定された $C_{p}$ を基に， $\alpha$ 方向の直

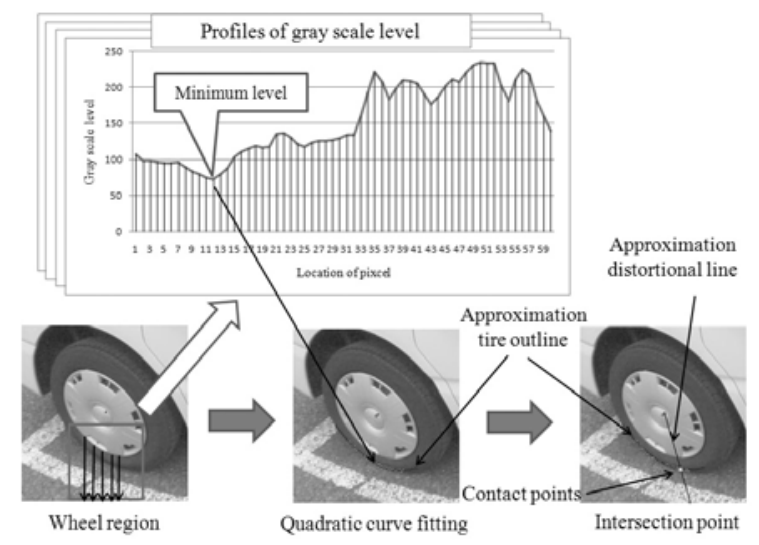

Fig. 5 The flow detecting the contact points using the gray scale profiles 
線を求める.この近似曲線と直線の交点を計算して， $G_{p}$ をサブピクセル精度で検出する . 提案方法では, 濃淡值 プロファイルの探索においてノイズによる影響を多少受 けても, 複数の濃淡值プロファイルを用いて曲線近似す ることにより，乥の影響は軽減されるため, タイヤ接地 点は安定して検出される .

\section{5. 実験結果と考察}

提案方法の有効性を検証するために，タイヤ接地点の 検出と位置推定に関する実験を行った . 実験に用いたカ メラ仕樣を Table 1 に示す. 実験ではカメラ光軸を地面 に平行とし，高さ $100 \mathrm{~cm}$ に三脚で固定して車両を撮影 した . また，現時点での車載カメラの低解像度な環境を 考慮して，取り込まれた画像を $1170 \times 1170$ 画素の矩形 領域 (円周魚眼部分の有効画素数はおよ光 108 万画素, 画角に対する解像度 $6.5 \mathrm{pixel} /$ degree) に切り出して処理 を行った．処理対象は，駐車場内に駐車された 10 台の 車両の側面画像とし，カメラから車両側面までの距離 $Z$ は $30 \mathrm{~cm} \sim 300 \mathrm{~cm}$, カメラ光軸から車輪までの距離 $X$ は $0 \mathrm{~cm}$ × $300 \mathrm{~cm}$ の範囲で撮影を行った .なお，処理 プログラムの開発は Mathworks 社の MATLAB を用い て行った。

まず，特徵点の位置ずれを考慮したタイヤ接地点のサ ブピクセル検出の精度を評価するために行った位置推定 に関する実験結果を Table 2 に示す.この表は提案方法 と歪み角を考慮しないホイール中心位置の真下の接触点 を用いる方法および歪み角方向への濃淡值プロファイル を用いる方法の三つについて，検出された接地点から推 定される位置 $X, Z$ の値と道路平面上の実測値との誤差 の平均値および標準偏差を示す. 距離 $D$ の結果は $X, Z$ の二つの値から換算した值を用いた .なお，提案方法の 結果の距離に対する誤差率は, 平均 $2.3 \%$ で, 標準偏差は $1.5 \%$ であった .ここでの実測值はマニュアルで $0.1 \mathrm{~cm}$ の精度で計測したものである . 処理対象は 10 台の車両 の 80 枚の画像であり，表は 160 個の車輪の接地点位置 の推定結果である .この結果より，歪み角を考慮した提 案方法はいずれの值も平均值 $5 \mathrm{~cm}$, 標準偏差 $4 \mathrm{~cm}$ 以下 の誤差であり，キャリブレーションを行っていないにも かかわらず, 良好な結果が得られた .

実際の計測における誤差原因としては，接地点検出に おける画素位置のずれや撮影時のカメラの高さ，パン角， チルト角, ロール角の変動および対象となるタイヤ半

Table 1 Camera specification

\begin{tabular}{|l|l|}
\hline $\begin{array}{l}\text { Disital still } \\
\text { camera }\end{array}$ & $\begin{array}{l}\text { Canon EOS Kiss Digital N } \\
3456 \times 2304 \text { pixels }\end{array}$ \\
\hline \multirow{3}{*}{ Lens } & $\begin{array}{l}\text { SIGMA 4.5mm F2.8EX DC } \\
\text { CIRCULAR FISHEYE HSM } \\
\end{array}$ \\
& $\begin{array}{l}\text { Angle of view: 180 degree } \\
\text { Projection system: Equi-solid angle }\end{array}$ \\
\hline
\end{tabular}

径の差異が考えられる.ここでは，これらの原因による 個々の誤差を, 前述の位置推定方法に基づくシミュレー ションにより理論的な推定を行った . 本来は接地点であ る画素位置から关の 8 近傍のいずれかに接地点が誤検出 された場合の誤差を計算すると, カメラからの距離に応 じて大きくなり，光の誤差の最大值は約 $9 \mathrm{~cm}$ で, 距離 に対する誤差率は最大 $2 \%$ 程度であった . また , カメラ 高さの $\pm 2 \mathrm{~cm}$ の変動に対する誤差率は $2 \%$ であった . パン角, チルト角, ロール角が爫れ芘れ 1 度変動した 場合の誤差率は，パン角は $0 \%$ であるが , チルト角で $4 \%$ ，ロール角で $3.5 \%$ 程度であった .さらに，実験対 象とした車両のタイヤ半径が $25 〜 35 \mathrm{~cm}$ と異なっていた 場合の誤差率は最大で $1.5 \%$ であった . 実際にはこれら の原因が複合して誤差が生じることもあり，実験結果の 誤差率は理論的に評価しても十分妥当な範囲であると考 える。

また，Table 2 で歪み角を考慮しない方法と比較して も，車輪位置 $Z$ よりも $X$ において，大きく改善されてい ることがわかる .さらに, 歪み角の方向への濃淡値プロ ファイルを用いるサブピクセル精度の検出方法による推 定結果と比較しても, 位置 $X, Z$ のいずれも, 提案方法 が良い結果であつた . Fig. 6 にこれら二つの方法による タイヤ接地点の検出例を示す. 黑い直線が中心射影点 $C_{p}$ から歪み角 $\alpha$ 方向への直線, 白い曲線が検出されたタイ ヤ接触点列の 2 次の近似曲線を示す. 交点の四角い白点 が提案方法による検出点であり, 丸い白点が $\alpha$ 方向の濃 淡値プロファイルを用いた方法で誤検出された点である． この図のように $\alpha$ 方向の濃淡值プロファイルだけではノ イズによる影響で誤検出となる場合でも，提案方法では 正しく接地点が検出されていることがわかる .これらの 結果から, 提案方法による接地点検出がサブピクセル精 度で, 高精度に位置推定が行えていることが示された。

つぎに,さまざまな位置におけるタイヤ接地点の検出 結果を Fig. 7 に示す . 図は処理結果の円周画像の下半円 部分と关のタイヤ部分の拡大画像を示す. 白点がタイヤ 接地点を示し, 白線は抽出されたホイールの中心点とタ イヤ接地点を結ぶ . これらの結果より, 弚れ帒れの画像

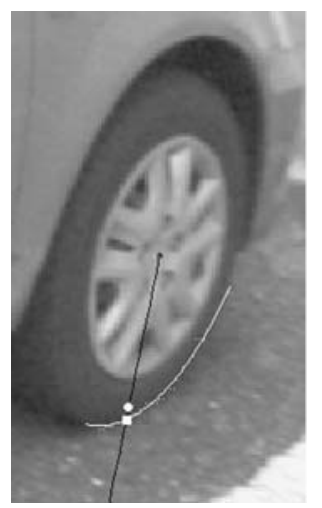

Fig. 6 Example of detected points 
Table 2 Results of position estimation (Ave. : Average, Std. : Standard deviation)

\begin{tabular}{|l|c|c|c|c|c|c|}
\hline \multirow{2}{*}{ Eethods } & \multicolumn{2}{|c|}{ Position $X[\mathrm{~cm}]$} & \multicolumn{2}{c|}{ Position $Z[\mathrm{~cm}]$} & \multicolumn{2}{c|}{ Distance $D[\mathrm{~cm}]$} \\
\cline { 2 - 8 } & Ave. & Std. & Ave. & Std. & Ave. & Std. \\
\hline Proposed method & 3.4 & 2.6 & 4.1 & 3.4 & 4.9 & 3.7 \\
\hline Underneath center point & 7.4 & 6.0 & 4.3 & 3.6 & 7.4 & 6.5 \\
\hline Distortional direction(sub-pixel) & 3.7 & 2.9 & 4.2 & 3.6 & 5.1 & 4.2 \\
\hline
\end{tabular}

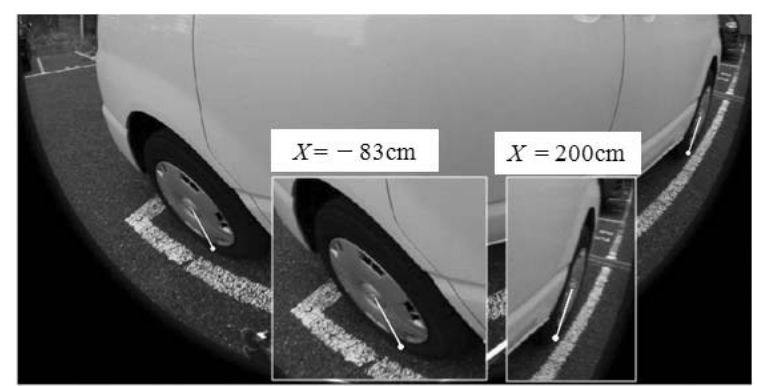

(a) $Z=50[\mathrm{~cm}]$

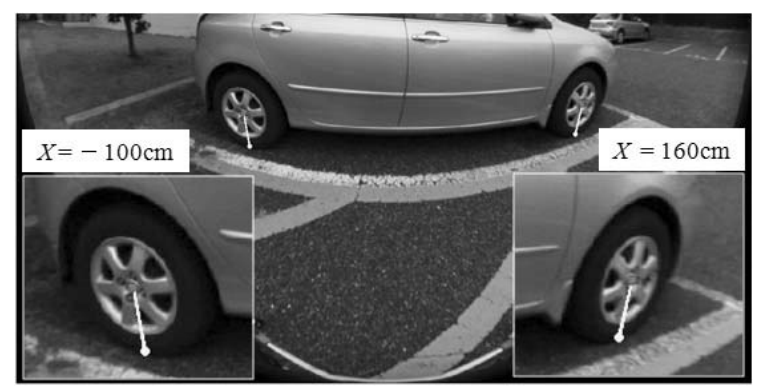

(b) $Z=150[\mathrm{~cm}]$

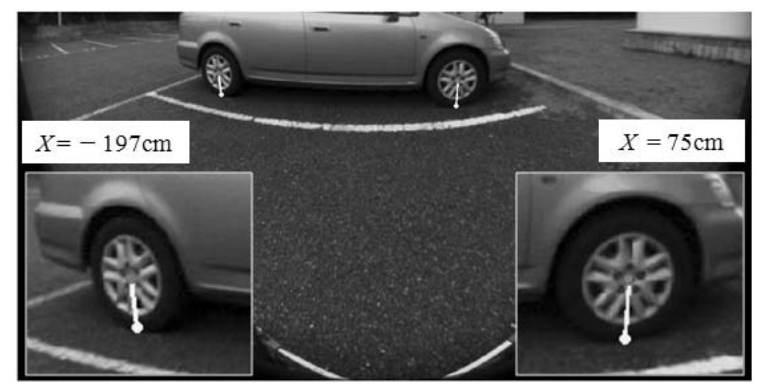

(c) $Z=250[\mathrm{~cm}]$

Fig. 7 The detected results at several positions

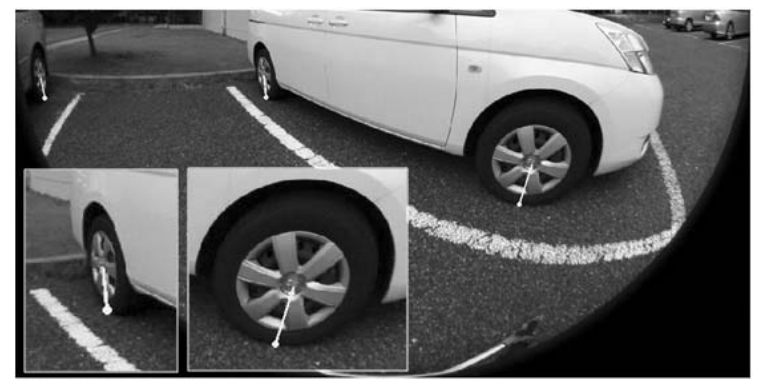

Fig. 8 The detected results of oblique wheels
Table 3 Results of wheel extraction

\begin{tabular}{|c|c|c|c|}
\hline $\begin{array}{c}\text { Number of } \\
\text { images }\end{array}$ & $\begin{array}{c}\text { Two wheels } \\
\text { extracted }\end{array}$ & $\begin{array}{c}\text { One wheel } \\
\text { extracted }\end{array}$ & $\begin{array}{c}\text { Not } \\
\text { extracted }\end{array}$ \\
\hline 122 & 100 & 14 & 8 \\
\hline
\end{tabular}

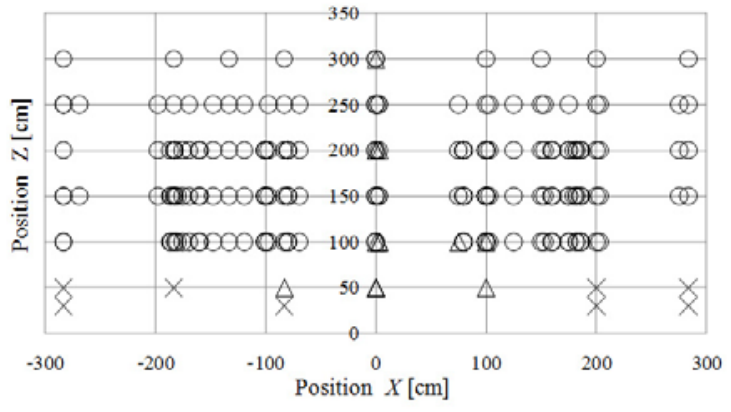

OTwo wheels $\Delta$ One wheel $\times$ Not extracted

Fig. 9 The extracted wheels on road position

位置に対応して歪み角が正確に考慮されており，接地点 が正しく検出されていることがわかる．また，車両のホ イール面がカメラ光軸に水平な傾きをもつ場合の検出結 果をFig. 8 に示す. 先に述べたパラメータテーブルは， ホイール面がカメラ光軸に垂直に面していると仮定して 計算されるが, 接地点の歪み角は, 接地点位置における 地面に垂直な線分に対する歪み角であり，ホイール面の 傾きには影響されない. 図のようにホイール面がカメラ 光軸に垂直でない場合も問題なく接地点が検出されてい ることから，提案方法がホイール面の傾きに対してもロ バストであることが示された .

タイヤ接地点の検出はホイールが正しく抽出されるこ とが前提となるので, ホイール抽出の結果を Table 3 に 示す . この表より，未抽出はあるが，誤抽出はなく，お よ光 93 パーセントの画像で少なくとも一つのホイール が正しく抽出されており, 車両検出における提案方法 の有効性は示されたと考える.また, カメラとホイー ルの道路上の相対位置関係を Fig. 9 に示す . この図より $50 \mathrm{~cm}$ 以内に近づいたときは, ホイールの未抽出が多い が, $50 \mathrm{~cm}$ 以上離れていれば, ほとんど未抽出はなかっ た. ホイール未抽出の主な要因は, ホイール部分の方向 エッジ抽出段階での失敗であった . カメラからの車両位 置 $Z$ が $30 \mathrm{~cm}$ と非常に接近し, カメラからの車輪位置の $|X|$ が大きい場合は, 円周魚眼画像の周辺部でホイール 部分の歪みが大きくなるため, ホイール外側にあるタイ 
Table 4 Comparison of estimation methods (Ave. : Average, Std. : Standard deviation)

\begin{tabular}{|l|c|c|c|c|c|c|}
\hline \multirow{2}{*}{ Error } & \multicolumn{2}{|c|}{ Position $X[\mathrm{~cm}]$} & \multicolumn{2}{|c|}{ Position $Z[\mathrm{~cm}]$} & \multicolumn{2}{c|}{ Distance $D[\mathrm{~cm}]$} \\
\cline { 2 - 8 } & Ave. & Std. & Ave. & Std. & Ave. & Std. \\
\hline Proposed method & 3.6 & 2.7 & 3.0 & 2.3 & 3.5 & 2.7 \\
\hline Pinhole transformation method & 3.2 & 2.6 & 3.8 & 4.5 & 4.0 & 4.6 \\
\hline
\end{tabular}

ヤ部分が画像上に撮像されない場合がある .この場合は 方向エッジの抽出段階で未抽出部分が多くなり，ホイー ルが抽出されなかった . カメラからの車両位置 $Z$ が少し 大きくなると，ホイール抽出が可能となるが，タイヤの 偏平率が低い車の場合は，タイヤ高さが低くなるために， 車輪位置 $|X|$ が大きくなると，ホイールが抽出されない 場合もあった ·また，車輪位置 $|X|$ が大きくなるにした がい, 円周魚眼画像の周辺部に撮像されるため，ホイー ル形状が非常に細長くなり，丸みを持たない場合が多い． このとき個々の方向エッジが正しく抽出されても，抽出 される方向エッジの方向数が少なくなり，ホイールが末 抽出になる場合があった .しかし，これらの場合でも一 方の車輪位置 $|X|$ が小さい場合は, こちらのホイールが 正しく抽出されるので, 車両検出としての利用は可能で ある

また，魚眼カメラを用いるときの一般的な方法である 正像変換後に処理する方法との比較を Table 4 に示す. この方法では, 光軸方向について正像変換を行い, 変換 後の正像画像からエッジ抽出と八フ変換により円を抽出 し， 円の中心位置の真下の濃淡值プロファイルを探索す ることで接地点を求めた . 表の提案方法による推定結果 は，正像変換による方法て接地点位置が推定可能であっ た画像に対してのみ位置推定を行った結果である．この 結果では, 位置 $X$ において正像変換の方法が良いが， $Z$ においては提案方法が良くなっており，同程度の精度が 得られている.しかし, 正像画像は円周魚眼画像の中心 付近では正確に結果が得られるが, 円周周辺部に近づく にしたがって，解像度が低く，変換による歪みやぼけが 大きくなるために正しく円の抽出が行われず，ホイール の抽出精度が悪くなる.Fig. 10 に提案方法と正像変換 を用いた方法による検出結果例を示す．この例で正像変 換を用いた方法では, 後輪は正しく検出できているが， 前輪はぼけのためにホイールが抽出されなかった .この 方法でホイール抽出精度を上げるためには，あらかじめ ホイール位置を予測し，弚の方向に応じた正像変換が 必要となる . また, 提案方法は, カメラ設置の初期処理 としてパラメータテーブルの計算は一度だけであるが， 正像変換は魚眼画像を処理するたびに必要となり，弚の MATLAB での処理時間はパラメータテーブルの計算時 間のおよ光 20 倍を要した .このことから，提案方法が 処理コストの点でも優れていると考える .

さらに，実験環境や処理方法が異なるために単純に 比較はできないが, 参考までに他のカメラを用いた方

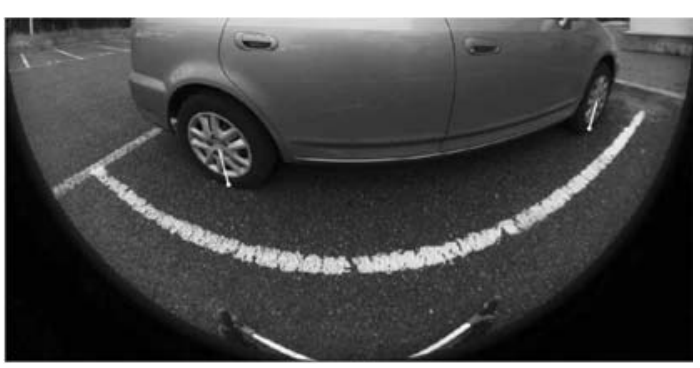

(a) Proposed method

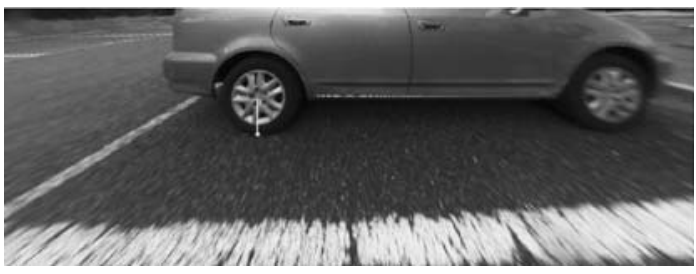

(b) Pinhole transformation method

Fig. 10 Comparison to pinhole transformation method

法の位置推定結果を基に考察する . 通常カメラを用い た方法として, C. Lai ら [7]は, 画角に対する解像度が 15pixel/degree 以上の画像にエッジ抽出とハフ変換を用 いて, カメラから $X$ 方向に $1 \mathrm{~m}, Z$ 方向に $3 \mathrm{~m}$ 程度の範 囲にあるタイヤの接地点位置を推定し, 平均推定誤差は $X$ 方向で $0.9 \mathrm{~cm}, Z$ 方向で $7.0 \mathrm{~cm}$ の結果を示した .こ の結果は提案方法と同程度の精度であるが, 通常カメラ ではタイヤは歪みのない円あるいは棈円となるため , こ の範囲における位置 $X$ の推定値は提案方法より安定した 結果が得られている. しかし, 通常カメラの標準的な水 平画角を 60 度とすると， $Z$ 方向に $3 \mathrm{~m}$ の位置では $X$ 方 向にェ $170 \mathrm{~cm}$ 程度の範囲しか計測できない. また, 車 長 $4 \mathrm{~m}$ の車両側面を対象とする場合は, カメラから $3 \mathrm{~m}$ 以上の距離が必要となり, $3 \mathrm{~m}$ 以内の近距離車両の計測 には向かない．このことから, 提案方法は近距離で位置 計測できる範囲が広い点で, 通常カメラの方法よりも優 れていると考える．つぎに，才ムニカメラを用いた方法 として, S. K. Gehrig[13] は, 解像度 $6.6 \mathrm{pixel} /$ degree で正像画像に変換した後に, ステレオ処理により $8 \mathrm{~m}$ 以 内にある周囲物体の位置推定を行い, 平均推定誤差が $X$ 方向で $8.3 \mathrm{~cm}, Z$ 方向で $10.0 \mathrm{~cm}$ の結果を示した .この 結果はタイヤ接地点の検出を行ったものではなく，アプ リケーションとしての適用範囲は少し異なるが, 位置推 定値をみると, 提案方法の方が良く, 解像度も同程度で あることから，本方法の有効性が示されたと考える． 


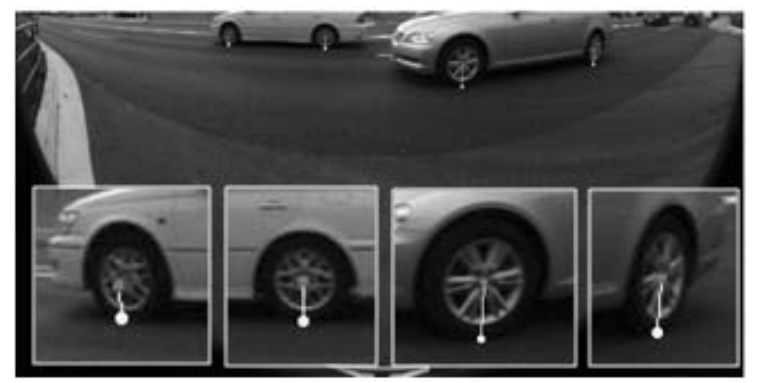

(a) Sedans (ISO:400, iris:f/10, shutter speed:1/400[s])

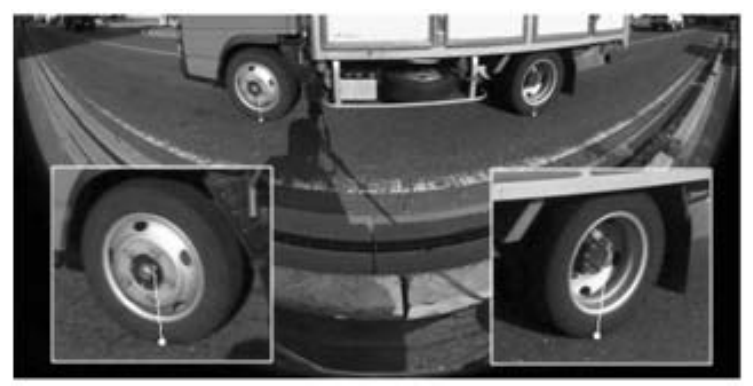

(b) Truck (ISO:400, iris:f/11, shutter speed:1/500[s])

Fig. 11 Detected results of moving vehicles

最後に，走行中の車両を対象にした検出実験の結果を 示す. 実験では，画像上の車輪部分に動きによるぶれが 生じる時速 $40 \mathrm{~km}$ 90 $\mathrm{km}$ の走行においてもタイヤ接地 点が検出できることを確認した . 検出結果例を Fig. 11 に 示す.この图は, 制限速度 $40 \mathrm{~km} / \mathrm{h}$ の幹線道路の路肩お よび歩道部分にカメラを設置して, カメラ光軸に垂直な 車線を走行中の車両 (車両位置 $Z$ は $150 \mathrm{~cm} \sim 600 \mathrm{~cm}$ ) を撮影した画像である．画像ごとの撮影条件は图に示す． この結果より，車輪部分に動きによる多少のぶ゙れが生じ る場合でも，タイヤ接地点が検出されることが示された .

\section{6. おわりに}

本論文では, 車両側面画像を対象として, 二つの同心 円の特徵点の位置ずれを考慮した円周魚眼画像における タイヤの接地点検出からの道路上の位置推定方法を提案 した．また，検証実験を通して产の有効性を確認した． ここでは, 車輪をホイールとタイヤの二つの同心円と仮 定して得られる歪みパラメータテーブルを用いた中心射 影点の推定と濃淡值のプロファイルを用いたタイヤ接地 点の検出方法を提案した . 濃淡值プロファイルを用いた 検出では, サブピクセル精度での検出法を提案して , 高 精度な位置推定結果を示した．また，ほかの位置推定方 法と比べても提案方法は高精度であり，超音波ソナーの ような近距離のアクティブセンサでも参考文献 $[16]$ によ ると $2 \sim 6 \mathrm{~cm}$ 程度の推定誤差があり，提案方法の平均推 定誤差は $5 \mathrm{~cm}$ 以内であることから近距離では実用上十 分な結果が得られた .これにより，狭い道路での交通量 計測，駐車場などにおける車庫入れ時の車両検出や，走
行中における駐停車車両や並列走行車両との車間計測な ど，さまざまな応用が可能と考える．

本提案方法ではカメラキャリブレーションを行わなく ても実用十分な結果が得られたが, 魚眼カメラのキャリ ブレーションを行えば, さらに高精度な位置推定が可能 となる、リアルタイムでの処理などを含めたシステム全 体の構筑に関する研究は今後の課題である.

\section{謝辞}

本研究は科研費 (基盤研究 (c):課題番号 19500162)の 助成を受けたものである.

\section{参考文献}

[1] Z. Sun, G. Bebis and R. Miller : On-road vehicle detection: A review; IEEE Trans. Pattern Analysis and Machine Intelligence, Vol. 28, No. 5, pp. 694-711 (2006)

[2] C. R. Wang and J. J. Lien : Automatic vehicle detection using local features - Statistical approach; IEEE Trans. Intelligent Transportation System, Vol. 9, No. 1, pp.83-96 (2008)

[3] S. J. Velat, J. N. Johnson and C. D. Crane III: Vision based vehicle localization for autonomous navigation; Proceedings of the 2007 IEEE International Symposium on Computational Intelligence in Robotics and Automation, pp.528-533 (2007)

[4] L. Zhi-fang and Y. Zhisheng:A real-time vision-based vehicle tracking and traffic surveillance ; Proceedings of the Eighth ACIS International Conference on Software Engineering, Artificial Intelligence, Networking, and Parallel/Distributed Computing, pp.174-179 (2007)

[5] T. Gandhi and M.M. Trivedi : Vehicle surround capture: Survey of techniques and a novel omni-videobased approach for dynamic panoramic surround maps ; IEEE Trans. Intelligent Transportation System, Vol. 7, No. 3, pp.293-308 (2006)

[6] 佐久間, 高橋ほか: パノラマ画像を用いた路肩停車車両 計数システム; 信学論 (D-II) , Vol. J85-D-II, No. 8, pp.1361-1364 (2002)

[7] C. Lai and W. Tsai : Location estimation and trajectory prediction of moving lateral vehicle using two wheel shapes information in 2-D lateral vehicle images by 3-D computer vision techniques; Proc. the 2003 IEEE International Conference on Robotics \&3 Automation, pp.881-886 (2003)

[8] O. Achler and M. M. Trivedi: Camera based vehicle detection, tracking, and wheel baseline estimation approach; IEEE Intelligent Transportation Systems Conference, pp.743-748 (2004)

[9] Y. Iwasaki and Y. Kurogi: Real-time robust vehicle detection through the same algorithm both day and night; Proc. of the 2007 International Conference on 
Wavelet Analysis and Pattern Recognition, pp.10081014 (2007)

[10] K. Kato, T. Nakanishi, A. Shio and K. Ishii: Structure from image sequences captured through a monocular extra-wide angle lens; Proc. IEEE Computer Society Conf. on Computer Vision and Pattern Recognition, pp.919-924 (1994)

[11] O. Achler and M.M. Trivedi: Vehicle wheel detector using 2D filter banks; Proc. IEEE Intelligent Vehicles Symposium, pp.25-30 (2004)

[12] T. Gandhi and M.M. Trivedi: Video based surround vehicle detection, classification and logging from moving platforms: issues and approaches: Proc. the 2007 IEEE Intelligent Vehicles Symposium, pp.10671071 (2007)

[13] S. K. Gehrig: Large-field-of-view stereo for automotive applications; OmniVis 2005 (2005)

[14] C. de Boor: A Practical Guide to Splines; SpringerVerlag New York, pp.43-50 (1978)

[15] 清水，奥富 : 画像のマッチングにおける高精度なサブピ クセル推定手法 ; 信学論 (D-II) , Vol. J84-D-II, No. 7, pp.1409-1418 (2001)

[16] K. Song, C. Chen and C. C. Huang: Design and experimental study of an ultrasonic sensor system for lateral collision avoidance at low speeds; IEEE Intelligent Vehicles Symposium, pp.647-652 (2004)

\section{著者略歴}

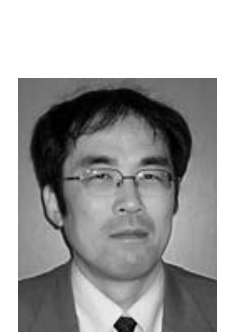

\section{健 (正会員)}

1964 年 1 月生. 1988 年大阪市立大学大 学院工学研究科電気工学専攻前期博士課程 修了. 産業技術短期大学電気工学科助手。 現在 , 情報処理工学科准教授.画像処理, コンピュータグラフィックス, ヒューマン インタフェース, ITS (高度道路交通シス テム) の研究に従事. IEEE, ACM, 電子情報通信学会, 情 報処理学会, 日本図学会などの会員 .

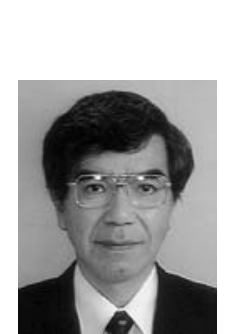

㧞

1951 年 6 月生. 1980 年京都大学大学院 工学研究科物理学第二専攻博士課程修了. 1982 年富士通研究所情報書影研究部入社, 2002 年大阪市立大学大学院工学研究科電 子情報系専攻教授 . 画像処理, コンピュー タビジョン，視覚情報処理の研究に従事． 理学博士. IEEE, 電子情報通信学会, 情報処理学会, 人工知 能学会, 映像情報メディア学会, 電気学会などの会員.

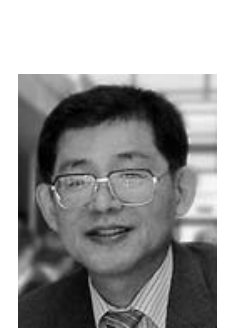

1946 年 2 月生 .1970 年大阪大学大学院 基礎工学研究科電気工学専攻修士課程修 了. 大阪市立大学工学部電気工学科助手, 情報工学科助教授, 工学研究科電子情報系 専攻教授を経て, 現在, 大阪市立大学名誉 教授.三次元動画像処理・理解 , パターン 認識, 学習機械, 変換群不変関数, ITS (高度道路交通シス テム) , 次世代マルチメディア検索エンジンなどの研究に従 事.工学博士. IEEE, 電子情報通信学会, 映像情報メディア 学会, 顔学会, センシング技術応用研究会などの会員. 